\title{
The cell cycle and why is it important for oncology
}

We have all felt a little embarrased when the media over-optimiscally transform an important scientific discovery into an imminent therapeutic breakthrough. Obviously, it is easier to discover and understand the intimacies of a new tumor suppressor gene than it is to develop an efficient treatment for an advanced cancer. However, and despite having said this, it should not be forgotten that better treatments will always be born in the laboratories and sometimes from the most unexpected areas of research. The present issue of Revista de Oncología includes a superb review by Amancio Carnero presenting an update of the mammalian cell cycle and its implications in oncology ${ }^{1}$. The recent progress in cell-cycle research exemplifies some of the above-mentioned issues: it has an enormous debt to the research done in model organisms such as yeast; it has generated a lot of expectations, particularly concerning the development of new diagnostic and therapeutic tools; but, with a few notable exceptions, these tools have not come yet.

The molecular study of the mammalian cell cycle rests on the shoulders of two "apparently unpromising" lines of research, the study of fertilized clam eggs and the genetics of yeast proliferation. The confluence of these investigations led directly to the isolation of "magic" enzymes that are able to trigger specific phases of the cell cycle. Nevertheless, as far as oncology is concerned, the coming-of-age of the cell cycle occurred in 1991 with the simultaneous discovery of cyclin D1 by the laboratories of Arnold, Beach, Sherr and Reed ${ }^{2-5}$. Cyclin D1 was immediately identified as the oncogene genetically mapped to the so-called B-cell leukemia locus 1 (BCL1) ${ }^{2}$; indeed, the rearrangement of cyclin D1 is used today by pathology laboratories around the world to diagnose mantle cell lymphomas ${ }^{6}$. Only eight years have passed since the discovery of cyclin D1 and during this time, the cell cycle has yielded more oncogenes and important tumor suppressors, such as p16 $6^{\mathrm{INK} 4 \mathrm{a}}$ (ref. 7) and

Rev Oncología 2000; 2: 1-2. p14 ${ }^{\mathrm{ARF}}$ (ref. 8). Moreover, these studies have had a tremendous success in explaining the actions of previously known tumor suppressors, particularly p53 and the retinoblastoma gene.

One of the most interesting themes of Amancio Carnero's review is that the normal functions of some oncogenes and tumor suppressors can be grouped into cell-cycle regulatory pathways. This is the case of the $\mathrm{p} 16^{\mathrm{INK} 4 \mathrm{a}} / \mathrm{CDK} 4 / \mathrm{cycD} 1 / \mathrm{Rb}$ pathway and the p14 ${ }^{\mathrm{ARF}} / \mathrm{MDM} 2 / \mathrm{p} 53$ pathway. Even more, some of these pathways may be universally deregulated in all cancers, or at least in all advanced cancers. This does not mean that we should not pay attention to the specific alterations present in a particular cancer. For example, it is well-established in cell culture studies that loss of Rb or overexpression of cyclin D1 can sensitize the cell to die by apoptosis, whereas loss of $\mathrm{p} 16^{\mathrm{INK} 4 \mathrm{a}}$ is not associated with a pro-apoptotic state. Also, mutation of p53 is associated with some degree of resistance to DNA damaging agents, whereas loss of p19 ${ }^{\mathrm{ARF}}$ does not affect the sensitivity to DNA damage. In other words, a p16 ${ }^{\mathrm{INK} 4 \mathrm{a}}$-deficient tumor may behave differently than an Rb-deficient tumor, and a p19 ${ }^{\mathrm{ARF}}$-deficient tumor may also behave quite differently than a p53-defficient tumor. These are issues that have not been investigated yet in full detail, and that need to be addressed.

Another important scientific challenge is to integrate the cell cycle into a broader picture that will include cell-adhesion and motility, cell death, mitogenic signaling, stress responses, and genetic stability. In this regard, for example, there is now evidence linking the cell-adhesion regulatory system of APC/ $\beta$-catenin to cyclin $\mathrm{D} 1^{9}$ and $\mathrm{p} 53^{10}$. Another interesting example comes from the observation that cells with a "deregulated"-cell cycle have an unusually high level of Apaf-1, caspase-9, or cytoplasmic cytochrome c; however, and for unknown reasons, these events are not effective in triggering apoptosis, a phenomenon that can be abbreviated as "priming without engaging"11. The characterization of these complex networks will hopefully have consequences for the development of better diagnostic tools and more efficient treatments. 
The study of the cell cycle is still in its infancy, but judging from its short history I can only be optimistic about its future in oncology.

\section{Manuel Serrano}

Científico titular del CSIC. Centro Nacional de Biotecnología. Madrid. Correo electrónico: mserrano@cnb.uam.es

\section{References}

1. Carnero A. Cell cycle and cancer. Rev Oncología 2000; $1: 12-22$.

2. Motokura T, Bloom T, Kin HG, Jupner H, Ruderman JV, Kronenberg $\mathrm{HH}$ et al. A novel cyclin encoded by a bcl1linked candidate oncogene. Nature 1991; 350: 512-515.

3. Xiong Y, Connolly T, Futcher B, Beach D. Human D-type cyclin. Cell 1991; 65: 691-699.

4. Matsushime S, Roussel MF, Ashmun RA, Sherr CJ. Colony-stimulating factor 1 regulates novel cyclins during the G1 phase of the cell cycle. Cell 1991; 65: 701-713.
5. Lew DJ, Dulic V, Reed SI. Isolation of three novel human cyclins by rescue of G1 cyclin (Cln) function in yeast. Cell 1991; 66: 1197-1206.

6. Bosch F, Jares P, Campo E et al. PRAD-1/cyclin D1 gene overexpression in chronic lymphoproliferativedisorders: a highly specific marker of mantle cell lymphoma. Blood 1994; 84: 2726-2732.

7. Serrano M, Hannon GJ, Beach D. A new regulatory motif in cell-cycle control causing specific inhibition of cyclin D/CDK4. Nature 1993; 366: 704-707.

8. Quelle DE, Zindy F, Ashmun RA, Sherr CJ. Alternative reading frames of the INK $4 a$ tumor suppressor gene encode two unrelated proteins capable of inducing cell cycle arrest. Cell 1995; 83 : 993-1000.

9. Tetsu O, McCormick F. $\beta$-Catenin regulates expression of cyclin D1 in colon carcinoma cells. Nature 1999; 398: $422-426$.

10. Damalas A, Ben-Ze'ev A, Simcha I, Shtutman M, Martínez Leal JF, Zhurinsky J et al. Excess $\beta$-catenin promotes accumulation of transcriptionally active p53. ЕMBO J 1999; 18: 3054-3063.

11. Guo M, Hay BA. Cell proliferation and apoptosis. Curr Opin Cell Biol 1999; 11: 745-752. 